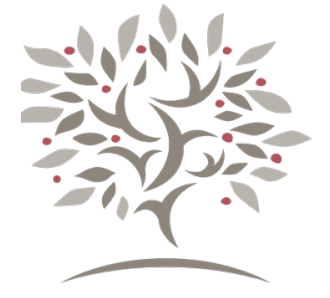

ARTICLE

\title{
Diverse Muslim Narratives: Rethinking Islam 101
}

\author{
Hussein Rashid \\ Independent Scholar
}

\begin{abstract}
A B S TRACT
At this point, the critique of the study of religion as emerging out of a normative Christian framework is well-established in the field. Edward Said's argument for the ways in which Islam is constructed to meet American political interests, rather than an engagement with Muslims and their religion, is nearly forty years old. These power dynamics mean that students, through popular discourse, understand Wahhabi Islam as Sunni Islam, which they consider the "true Islam" against which other Islams are judged. I propose a model of looking at how Muslims define their religion through contestation and relation which allows students to understand the dynamic nature of their traditions. The approach I outline gives a greater breadth of material represented by a global religious community with over a millennium of history.
\end{abstract}

\section{KEYWORDS}

Islam, world religions, orientalism, arts, authority

\section{Introduction}

Over the last several years of teaching courses related to Islam, I have had to contend with what students think they know about the religion. ${ }^{1}$ Most of the time, their knowledge is framed by media coverage of Islam (Salem 2016). ${ }^{2}$ This has been true in multiple contexts: a small liberal arts college, a large public university, several large private universities (including an R1), and several non-Muslim seminaries. Initially, I tried to understand that knowledge base and to engage it. However, I quickly realized that such an approach did not allow me to teach the richness of Islam, nor does it actually help the students learn. Starting with their preconceived notions of what Islam is reinforces that what they think is correct, and makes it more difficult for me to introduce a more expansive vision of Islam (Lakoff 2014; Ecker, Swire, and Lewandowsky 2014; Chan, Jones, Jamieson, and Albarracín 2017; Peter and Koch 2019). ${ }^{3}$

1 I am indebted to the 2017-2018 Wabash Center Colloquy on Writing the Scholarship of Teaching in Theology and Religion, for the space, time, and funding to work on this article. In particular, the critical eyes of Thomas Pearson, Eugene V. Gallagher, Kwok Pui-Lan, Beverley McGuire, Jenna Gray-Hildenbrand, David Howell, and Martin Nguyen were helpful to me during my process. Thanks to my reviewers, especially the one who encouraged me to think of faith (iman) and religion ( $\mathrm{din}$ ) from within Muslim contexts.

2 For a brief discussion of how the university perpetuates media descriptions of Islam, see Kurzman and Ernst (2012, 26).

3 I rely on communications training that I have done to inform my reframing. I start with the knowledge in the frame I wish them to have, so that 
In time, instead of meeting students where they were, and risk validating incorrect information, I started to teach Islam as though none of them had any knowledge of the religion. There were two major problems with this approach. The first problem was that students believed that they did know something. That belief was not incorrect; they did know something, and I was not showing them the respect of engaging with what they knew, whether to amplify or to correct that knowledge (Ambrose 2010, 10-39). I needed to demonstrate that they had knowledge, without validating that knowledge as correct. The second problem was that my reaction validated their perception of Islam as $a$ tradition.

I questioned what I wanted students to understand, at a basic level, about Islam. I wanted to reveal to them the work of the discipline (Smith 2014). For me, this is that Islam is compromised of believers, Muslims, who are making meaning in a bounded system. In essence, I need to focus on a basic religious studies methodology: why people believe what they believe and how they express those beliefs. With that realization, I rethought how I approached my introduction to Islam.

Intellectually, I knew the formation of the study of religion was biased towards a baseline of Christianity as to what constituted true religion. (For an exploration of what this bias looks like in institutional practice, see Gallagher [2018]). The study of Islam inherited some of these structural biases, producing images of a normative Islam, Sunni Islam, and a heterodox Islam, Shi'i Islam. This construction shaped media images of Islam, which students were consuming. In response, I constructed an introduction to a method that was based on a religious literacy approach, which speaks to questions of context and power. The narrative of Islam I constructed was about contestations of power and leadership in the community, and how religious texts are utilized to explain and construct different models of authority.

This structure allows me to say to students, "You may have some information, but there is a method to how we will approach that information," so they feel respected, and can focus on the process of what we are doing (Nilson 2016). I guide them to understand that religion does not exist outside of the world, but is shaped by material realities. I can illustrate that different Muslim communities exist, and exist in relation to one another, so that I am not reifying "Islam" in a different way than the media might. They hopefully witness Islam as a living tradition that has importance to adherents of the religion (Khoja-Moolji 2014).

This article presents how I have structured my courses to consider critiques of the study of religion, student learning, and the diversity of ways of being Muslim. Some of this information will be familiar to those who specialize in teaching Islam, although there is new material for specialists. My hope is that this piece will be useful to those who are teaching about Muslims, either as specialists or non-specialists, in constructing their courses. The broader theoretical interventions can also be applied to the study of other religious communities and other lived traditions.

The structure of my current class introduction focuses on lived traditions to illustrate the principles of religious literacy. The readings I give students provide grounding knowledge with which I believe they should be familiar, and to which the class can refer for a common vocabulary. Barring questions from the students, class time is not spent discussing the readings, upon which they have done short reflection papers, but on illustrating the principles that should be drawn out from the week's work. The material is also structured to be spiraling, so that there is a clear methodological center to the work we are doing-there are many understandings of Islam that emerge from different contexts-and so that students can make connections across different units. Each unit ends with a demonstration of how Muslims are living their lives in the present day, so students witness the vitality of Muslim traditions. My primary concern in this article is how we educators can better teach the diversity of Muslim traditions through course design. Part of the design is based on student feedback and looking at how students are demonstrating their learning. While an extended discussion of student learning is beyond the scope of this paper, it is an important input in the structure, through formal and informal mechanisms. The following course outline is for the first half of a class that meets for fourteen to fifteen weeks, twice a week, for seventy-five to ninety minutes per class.

becomes our common environment. Peer learning allows them to critically approach incorrect framing and information, without me telling them they are wrong. Students also restate their knowledge in a sympathetic frame for the class, which should be more durable than simply repeating what I suggest as a frame.

144 2021; 2:1 143-158 The Wabash Center Journal on Teaching

This work is licensed under a Creative Commons Attribution-NonCommercial 4.0 International License 


\section{Study of Religion and Study of Islam}

The category of religion is one that is imposed from outside a tradition, and as such, inherits the biases of the observer (Morgenstein Fuerst 2014, 226). As the study of religion emerges as a discipline distinct from theology, it maintains Christianity as the "normative paradigm" for understanding what religion is and should be (King 1999, 36). Using Christianity as the model for religion is masked by the language of objectivity and secularism (Asad 1986, 23; King 1999, 42-43; Morgenstein Fuerst 2014, 229). Emic notions of what a religious life could mean are submerged into an "objective standard" of what a religion is, without any attention given to the fact that not all religions are Christianity. As other traditions are measured against Christianity they are found wanting, so the study of religion is invested in the process of othering. The category of "world religions" is a manifestation of this othering process (Masuzawa 2005, 22, 49).

In this context, Islam is constructed through its textual tradition, favoring the language of Arabic and the legalistic mode of the religion over other methods of interpretation (see Kurzman and Ernst 2012). Other understandings of Islam are treated as deviations from the religion. There is no understanding or investigation of how regional situations affect the practice of the religion; that work is coded for area studies, not religion (Hodgson 1974a, 40). This simplified view of Islam is reinforced through academia, media, and governmental agencies (Said 1981, 136). The result is an anthropomorphized Islam-so that "Islam" is treated as a person with agency of its own-where the actions and beliefs of Muslims are irrelevant; this construction of Islam is the "true" understanding of the religion.

I argue that this "Islam" is described and manifested through two mechanisms: culture talk and scripturalism. Culture talk is the reduction of complex facets of a religion to a deterministic essence which explains the actions and behaviors of Muslims (Mamdani 2004, 17-62; Reinhart 2002, 24). Scripturalism is predicated on a Protestant understanding of scripture, whereby the Qur'an determines the behavior of a Muslim without consideration of any other factor (Ernst 2003, 55).

The construction of a legalistic, Arab tradition that can be essentialized and indexed to a preferred form of Christianity results in a Sunni Islam emerging as the normative Islam. But Sunni Islam is no more orthodox than other traditions: there are a multitude of interpretations determined by time and place. According to historian Farhad Daftary, orientalists "studied Islam according to Sunni perspectives and, borrowing classifications from Christian contexts, treated Shi'ism as the 'heterodox' interpretation of Islam, or even as a 'heresy,' in contrast to Sunnism which was taken to represent Islamic 'orthodoxy”' (Daftary and Miskinzoda 2014, 55). The theology of Sunni Islam did not recognize Muhammad's designation of a successor to his spiritual and religious role: his cousin and son-in-law Ali. The group that did recognize Muhammad's designation are known as the Shi'ah, short for Shi'ah Ali (supporters of Ali).

With this knowledge of the biases of the field, we scholars must think through how we teach about religion generally, and Islam specifically, to ensure that the diversity of voices within a tradition emerge. We also have to be careful to not simply present a laundry list of interpretations, without providing them within a web of meaning, including contexts and relationships (see Gaiser 2017). A cultural studies approach allows this sort of reimagining of the field.

\section{Cultural Studies}

Islamic studies scholars Carl Ernst and Richard Martin ask the key question for thinking about how to restructure an introduction to Islam: "why should the study of other [non-Arabic legal discourses] historically important (if not outright dominant) Islamic discourses such as Sufism, Shi'ism, philosophy, poetry, ethics, and history be ignored or dismissed in an effort to maintain an old, some might say 'Orientalist,' criterion of what is authentic or normative?” (2010, 14). By asking this question, we must confront not just the "why" of the current structure, but the "how" of creating something different.

Obviously, even a full semester introductory course could not meaningfully cover every aspect of Muslim understandings of Islam. However, even a truncated introduction should be enough to demonstrate (and help students internalize) that a variety of "Islams" exist (Asad 1986; El-Zein 1977). Talal Asad, an anthropologist, offers a way to recognize the contextual nature of interpretation of Islam, and the particularities of the expressions of those interpretations. He says, "the variety of traditional Muslim practices in different times, places, and populations indicate the different Islamic reasonings that 
different social and historical conditions can or cannot sustain" (Asad 1986, 23). Asad would have us look at the meanings Muslims make of their tradition synchronically, and how those meanings define community (see Blizek 2009, 103; Hahn Tapper 2016).

In order to adapt Asad's insights into a structure for the course, I turn towards the Birmingham school of cultural studies. In part, their orientation is to "enhance and celebrate" social experience while understanding the causes of those experiences, and to recognize culture as everyday experiences, not something distinct from daily life (During 2005,1 ). Both elements recognize the role believers have in generating their own understanding of religion, preventing us, as observers, from giving defining descriptions of what it means to be Muslim. Our sense of religion moves from being based on Christianity as a theological model, to the traditions people inherit and create on their own terms (King 1999, 42-43). From a pedagogical perspective, as students investigate a practice of religion that situates it in materialist constraints, they remove any notion that they can provide an "objective" definition of the religion; as observers, they are forced to recognize that they too are situated in particular circumstances that affect what they see.

In this educational position, we teachers must also be conscious of moral relativism. As religious education scholar Diane Moore states, totalizing knowledge and claims to objectivity and moral relativity are mirror images of each other. They allow the observer to deny responsibility and critical inquiry. Using multiple partial views allows us to actually generate a critical discourse (Moore 2007, 79-80).

For my approach to introducing Islam, I look at competing notions of leadership. These contestations of interpretations and of orthodoxies allow us to understand questions of relational claims to power (Lewinstein 2002, 52-53; Martin and Barzegar 2010, 182-186; Wheeler 2002, 11). I can situate the claims in history without making judgements as to which claim is the "true Islam" (see Hashemi and Postel 2017, 4-5). Since there is no declaration of a "correct" belief, I can also look at multiple ritual expressions of religion without offering a value judgement as to whether they are "Islamic," and simply observe what Muslims do. At the same time, I can discuss internal criticisms and defenses of theologies and practices.

\section{Proposed Structure}

To take the ideas of contested orthodoxies seriously, I must demonstrate to my students the ways in which the foundational texts of the religion are read. Religion scholars Laurie Patton, Vernon Robbins, and Gordon Newby speak of exercises that engage students in "interactive interpretation" $(2009,38)$. They put texts in conversation with one another across different religious traditions, while I have students focus on the same texts within the same tradition (see Nilson 2016). In this approach students engage with the same texts but with new parameters that allow them to see the texts differently. While Patton, Robbins, and Newby work across schools of thought in order to push bounds of comparative thinking, my approach focuses on a small set of verses from the Qur'an and traditions of Muhammad (hadith), to see how different Muslim communities approach identical texts.

Since students often have limited knowledge of Islam or Muslims beyond news media, my early grounding of the material is a hybrid approach that integrates history, politics, and religious literacy. As a result, the first few weeks of my courses tend to be more didactic than exploratory as I tell students what I think it is important for them to know. (Later in the course, the exploratory element predominates as we discover what is important together.) Once those initial parameters of the discussion are established, students are more comfortable engaging with the material and have a greater sense of ownership of it.

This brief outline shows how I structure the beginning portion of my courses. Many of the courses I teach do not require a prerequisite, so I find this basic outline useful for all my courses, from the Introduction to Islam to Islam and the Modern World to Muslims in America. I am also conscious that, as Gene Gallagher notes, my course may be the only class in religion that a student takes; I am responsible for contributing to their religious literacy in general, and their knowledge of Islam in particular (Gallagher 2009, 210; see also Smith 2014, 79).

146 2021; 2:1 143-158 The Wabash Center Journal on Teaching

This work is licensed under a Creative Commons Attribution-NonCommercial 4.0 International License 
My courses are organized by topics to indicate that they are not comprehensive units but spaces where I can enter into a discursive tradition for particular pedagogic aims (see Patton et al. 2009, 39). For example, the particular Qur'anic selections I use for an Islam and the Arts course would be different than what I use for an Islam and Politics course. However, in both instances, I want students to understand the role the Qur'an plays in the lives of Muslims, and that the ways in which groups make meaning of the text are always contextually constructed.

My approach is less historical and less prescriptive than others (Gaiser 2011) and more focused on diverse understandings of religious texts. This is what works for me in my Introduction to Islam course, how it fits into my educational approach to the study of Islam, and what choices I make to achieve those ends. Educators, I hope, will recognize where I am playing to my personal strengths and see ways in which they can play into their own strengths. The key point is to understand how my approach destabilizes a type of normative Islam that may appear in an introduction to Islam. The goal is to show the diversity in understandings of Islam that Muslims hold.

The basic structure of each unit begins with a broad outline of the material being studied, usually expressed in the topic title. As a class we then look at some text together. This text is usually not from the reading, which they have done and written a response to before class. We read the in-class text through the lens of the work they have done at home and understand how the theory is put into practice. These discussions are interspersed with audio-visual material, so students can witness the ways in which Muslims experience and express the interpretative details we are discussing. We discuss the material I curate to show how expressions change through time and place. In addition, my selections demonstrate that theoretically rigid boundaries of interpretation are in fact practically porous, so that students witness communities of interpretation borrowing from each other.

\section{Topic 1: Study of Religion}

Since my courses are usually offered through a religion department, the first week is an introduction to the field and the premises from which we will operate. The syllabus generally has some variation of the statement: "We [as a class] are not interested in determining if a particular understanding [of religion] is right or wrong. Rather, we want to understand the roles religion plays in society and for the individual." This statement opens an avenue to discuss our purposes: to observe truth claims, rather than make truth claims as to what Islam is. Therefore, as students of how religion functions, we will witness numerous competing truth claims. The key point of this introduction is for students to understand that religions are not monoliths, and that the understanding and practice of believers' religions is conditioned by the world in which they live. The introduction has to avoid a slide into moral relativism, where students suspend critical apparatus. Rather, we are interested in the context of the truth claims and how they relate to one another. It is at this point we discuss the work of Diane Moore $(2006,2007)$, an expert on religious literacy. Based on her work, and the selected reading the students have to engage with for the class, we establish certain parameters for the ways in which we expect to approach religion (Moore 2006). These parameters of religious literacy are:

Knowing the basic tenets of a religious tradition. We need to know the basic descriptive elements of religion, such as the core beliefs that make them unique from other religions, including how adherents define their sense of self compared to other religions. This survey allows us to have a common vocabulary and to challenge some of the assumptions we make about defining religion.

We do an in-class survey using The Pew Forum's U.S. Religious Knowledge Quiz (Pew Research Center 2021). I read the questions out loud and students vote as to what they consider the correct answer to be. I then ask them, "Simply because you know that Ramadan is a holy month for Muslims, do you know anything about why or what it means for Muslims in their daily lives?" We also critique the idea that Catholicism and Mormonism are separate religions and not different understandings of the same religion according to Pew. Because students often recognize both as types of Christianity, they are are more willing to think about more than one type of Islam. 
Accepting that no religion is a monolith. This is easy to state but difficult to show, especially in a compressed time period. Showing contestations over how the religion is defined internally brings this point into relief, and the third point becomes more obvious.

Acknowledging diversity of expression in that tradition. Once students understand that meanings of the tradition are contested, they more easily understand that religion is expressed in a variety of ways. A majority interpretation is not the interpretation. For example, the first point of contestation for Muslim communities is the Qur'an. While individual Muslims may not consult the Qur'an for every issue, it is the point from which interpretation begins.

Understanding the way text functions, and the interpretations of the text. ${ }^{4}$ Believers use texts in a variety of different ways and that engagement with text, both as scholastic and devotional source, generates different readings of the text. To illustrate this point, I have students imagine they are Martians who come to the United States and look at the national "scripture" of the Constitution. We start by looking for the primary message of this scripture. Each class generates different answers, demonstrating that they cannot agree on a basic message. I then provide them with some selections about money, and ask them where the Constitution allows the federal government to print money, especially money that is not tied to a gold standard. This exercise encourages students to think about the extra-scriptural material that is part of the act of interpretation. In this case study, it is about the role of the judiciary.

Connecting the understanding of text to the ways in which religion is lived. In generating different interpretations of the text, adherents generate codes by which they will live, so that distinct rituals emerge. Conversely, ritual is also an act of interpretation, so that people may live according to what they believe the text says, without scholastic grounding.

Recognizing that culture and religion interact and define one another. Religion is tied to the material condition of adherents. The ways in which believers approach their religion is impacted by their social, economic, and political environments. In turn, the broader society reflects religious concerns, usually of the majority religion. We complicate the idea that religion and culture can be neatly separated and divided. In class we use a working definition of culture as the product of human activity and religion as a manifestation of a struggle with the ineffable, therefore religion is the product of human activity, or culture.

I ask the students when they have holidays during the school year and what they are called. They quickly realize that winter break is really a Christmas holiday, and spring break an Easter holiday. We also talk about how the phrase "under God" was added the Pledge of Allegiance as a response to the perceived Communist threat, and was not part of the text from its genesis.

We end the discussion realizing that religious illiteracy is not limited to those outside a tradition but can also be exhibited by those within a tradition who see their understanding of the religion as the only, true understanding of the tradition. The study of religion must take into account interpretation and context, it must be interdisciplinary, and it is based in a power analysis. This caveat ensures that we do not take one Muslim's assertion as to what Islam is at face value. Ending on this critique moves us into a discussion of how Islam is studied.

This material is important for framing the course. While I do not consistently mention the principles again throughout the course, they do determine how I construct later units. As conversation spaces open, I will mention or discuss them with the class, but emphasize the "show, don't tell" approach to the material. This framework also helps create an environment where regardless of what students think they know, from the media or lived experience, they are forced to think through specific categories that they may not have considered prior to this course. This allows students to be more open to moving beyond what they think they know.

4 Obviously, not all religious traditions have a written scripture to which they refer, but this course is Islam focused, so it is relevant.

148 2021; 2:1 143-158 The Wabash Center Journal on Teaching

This work is licensed under a Creative Commons Attribution-NonCommercial 4.0 International License 
The class starts with the premise that we need to look at questions of power and narrative. While cultural critic Edward Said's (1979) Orientalism is essential in understanding these questions, he does not directly address questions of religion in that work. Instead I assign students the work of a professor of Islamic studies, Carl Ernst (2003, 1-70), to bridge Said's work into the study of religion. This unit helps students understand how an identity is ascribed to Muslims, and the power of the describer.

We start the week with a discussion of a brief clip from the 1999 film The $13^{\text {th }}$ Warrior, which is based on a loose retelling of the travels of an actual tenth century Arab traveler, Ahmad ibn Fadlan, combined with the story of Beowulf. The clip is of the first encounter of Ibn Fadlan with the Vikings whom he eventually befriends. I ask students to write a bullet-point summary of how Ibn Fadlan would describe the Vikings. Without delving into details of the movie, the five descriptors of Vikings we generally settle on during discussion are:

1. Violent

2. Dirty/unhygienic

3. Superstitious/illogical

4. Have poor gender roles/misogynistic

5. Uncultured/uncivilized

This conversation demonstrates two things. The first is how who defines the other is based on power. In the tenth century, it is the Arab-Muslim world that is the center of world trade and artistic and intellectual production. Therefore, as Ibn Fadlan would see the Vikings, they are pathetic. The second thing is the limits on the ways in which the other can be defined by those in power. We take the descriptors they have generated for the Vikings, and see how the same ones are deployed against Muslim, Black, Latinx, or LGBTQ communities today. The structural issues become much more obvious to the students.

The students then read a short section of Orientalism, where Said begins to define the term. The passage states:

Taking the late eighteenth century as a very roughly defined starting point Orientalism can be discussed and analyzed as the corporate institution for dealing with the Orient-dealing with it by making statements about it, authorizing views of it, describing it, by teaching it, settling it, ruling over it: in short, Orientalism as a Western style for dominating, restructuring, and having authority over the Orient. (Said 1979, 3)

This selection demonstrates the institutions at play in establishing narrative control over a region, including academia, media, and governmental agencies (see also Said 1981, 161). In addition to the practical structure of Orientalism, which tells us such dominance is not accidental, we also look at the timing that Said puts forth, the late eighteenth century.

We use that time period to talk about the Enlightenment, the construction of the nation-state, and colonialism as a feature, not a bug, of the political and philosophical enterprises of this period. For this discussion, I draw heavily on the work of political scientist Mahmmood Mamdani (2004, 17-62). Informed by the work of religion scholar Tomoko Masuzawa, I return to the study of religion, and discuss the field's historic origins in this time period (2005). I help students understand that "religion" was indexed to Christianity, but the goal of a modern scholar of religion is to try to understand manifestations of religions on the same terms that adherents understand it, rather than in reference to Christianity or any other religious understanding with which they may be familiar (see Rashid 2018).

This discussion is reinforced by the introduction of Carl Ernst's use of "scripturalism," which he defines as "the expectation that one can understand everything of importance of the other religious traditions if one knows what is said in the their 
scriptures" $(2003,55)$. His assumptions mirror the theoretical arguments that the class has been discussing, as he grounds his critique in Protestant Christian understandings of how religion functions and the role of text. We then revisit the points raised in the previous week around religious literacy. We return to the exercise on the Constitution again, and I ask students how the dynamic would change if the Martian had a gun and told them that they did not know what it meant to be an American; it is a crude exercise in exploring power relationships and how external forces can shape understandings of a religion.

These two units establish premises and methods for the class. Our individual understandings of Islam are conditioned by institutional framings of Islam, which are usually constructed as a means to dominate Muslims. The political forces are paired with religious illiteracy, which divorces religious expression from any sort of context, and creates a narrow understanding of the religion. I explain to students that we need to keep these biases in mind as we learn about Islam. We need to try to understand Islam in the numerous ways Muslims understand it.

\section{Topic 3: The Qur'an}

We start with the Qur'an, the sacred text for Muslims. At this point in the course, there is still a concern that students may make incorrect connections to what they think scripture is and how it should function. Since the point is to understand the Qur'an in its own way, and the ways in which Muslims struggle with the text, I try to make it acceptable for students to be unfamiliar with the Qur'an. If students do not believe they need to know the Qur'an, they are less likely to engage in superficial comparisons with other religious texts, of which they may also have little understanding. I assign readings that presuppose no knowledge of the Qur'an or any scripture in general. The first is a video by popular author Lesley Hazleton (2010). It is a TED talk that focuses on what she was surprised by as an agnostic reading the Qur'an. I couple this with a reading by Islamic studies scholar and Christian theologian Whitney Bodman (2009). His work touches on the struggle of trying to approach someone else's scripture with the biases of his own worldview. He also introduces some of the structural elements of the Qur'an. I choose these two sources to help students to feel more comfortable being confused about how to approach the text, and to reinforce the work of the previous units on understanding our own perspectives in approaching the text.

The third reading, Sells (1999), focuses on the oral-aural nature of the Qur'an. The text emphasizes the fact that many words in the Qur'an cannot be translated into English without establishing one meaning of a word that has multivalent meanings. Sells also demonstrates the aesthetic qualities of the recited Qur'an, and the effect it has on listeners, even those who do not understand Arabic. This point is our first entry into how the text functions as an emotive recitation. ${ }^{5}$

In class, we start with a discussion of why they have no direct readings from the Qur'an, but only references to selections from the readings. The rationale for this is to avoid having them turn into amateur theologians, creating meaning from the text that would not be recognizable to someone from within the tradition, or that simply confirms the biases with which they entered the course. We will read selections from the Qur'an as we engage with how Muslims have interpreted the text to create boundary definitions for various Muslim “communities of interpretation" (Daftary 1996). With this approach I am not trying to mask the work of religious scholarship but to reinforce the idea that we will not practice scripturalism. It is a method that emerges out of what I have outlined as limits in historical approaches to the study of Islam. This exemplifies for the students that the text is open to interpretation within the confines determined by Muslim communities.

In the beginning of the Qur'an class, we talk about the history of revelation and how oral texts are transmitted. The next logical question is what happens when an oral text becomes a written text? The first development is the emergence of a commentary tradition, allowing for a scholastic tradition, giving further meaning to the text. We also talk about how the meaning of the text can become fixed.

On the screen I display the following set of words and ask students to punctuate them.

5 If time permits, students do a listening exercise where they listen to about six different recitations of al-Fatiha, and give their emotive responses after each one.

$150 \quad$ 2021; 2:1 143-158 The Wabash Center Journal on Teaching

This work is licensed under a Creative Commons Attribution-NonCommercial 4.0 International License 


\section{woman without her man is nothing}

Before asking them to tell me how to punctuate the sentence, I try to have a few of them read the words out loud. We then compare the reading and the unpunctuated sentence with two possible punctuated variants:

Woman, without her, man is nothing.

Woman, without her man, is nothing.

I point out that the words are the same, in the same sequence, with the exact same set of punctuation; only one comma is moved. This results in two sentences that give diametrically opposed meanings of the role of women in society. The "oral" text, which is unpunctuated, is open to interpretation by the listener. In the written version, the meaning is fixed, so the question of who is fixing the meaning becomes important. This discussion allows us to see that power determines what interpretation of religion is considered correct-it is not inherent in the text itself. The exercise is also a way for students to understand the contestations of meaning that occur and give rise to a diversity of interpretations within a tradition.

We end the unit with an exploration of calligraphy, which is enabled by the rise of the written text. Through this exploration, we see how scripture functions as devotional and artistic material, from amulets to monumental architecture.

\section{Topic 4: Prophet Muhammad}

After starting our study of the Qur'an, we turn to Prophet Muhammad, whom Muslims believe to have received the revelation of the Qur'an. The readings cover the history of the time in which he lived, his role in constructing ritual (both directly and indirectly), and as an object of devotion (Hussain 2010; Katz 2010; Saleh 2010). Our class discussions mirror this approach, looking at Muhammad as political figure, religious figure, and as a role-model and devotional figure for Muslims. Students need to see the overlapping roles Muhammad played in the community. He may be a prophet, but this is not a purely religious role. It entails having a role as a leader in the world, and as a model of perfection that Muslims want to emulate. Here, students should be able to recognize that to see Muhammad as having only one function limits their understanding of how Muslims interact with him. It is at this point that we can start talking about ritual, and differing ritual, amongst Muslims, as they look at the Qur'an and Muhammad for guidance on how to live their lives.

Our discussion of Muhammad as a paradigm starts with a verse from the Qur'an (33:21), where Muslims believe that God said that Muhammad was a "beautiful role-model." Therefore, in order to emulate Muhammad, Muslims need to know what he said and did, which is based on collected witness testimony known as hadith (tradition). We talk about the structure of hadith, and the ways in which people collected them and vouched for their veracity, and the grading of hadith. We then look at a short video of a lecture on Muhammad's relationship to one of his wives given at a gathering of Muslims (Sheikh 2012). The video shows how the hadith are turned into a narrative to offer moral guidance to believers, and become an important tool in the interpretative method.

From this exploration of Muhammad as a paradigm, we turn to another role of Muhammad-as an intercessor. This section turns to how the Qur'an deals with the power of intercession. We look at sections of the Qur'an to see how the Qur'an claims that all intercession belongs to God (39:44), that God can have someone else intercede (34:44, 2:225), the explicit endorsement of intercession (42:5), and that intercession will end (2:48). This reading of the text is the first of our provocations that looks at how the text is interpreted. We ask if the weight of text is such that intercession by a human being, like Muhammad, is impossible, or if possible, only for those God grants this ability to intercede. If it is the latter, we must then ask how do we know who was explicitly granted the authority. For the communities who do not believe in human intercessors, we question how they structure their religious life to come closer to the Divine. We end this part of the discussion with explicit references to Muhammad serving in the role of intercessor (48:10 and 4:64).

Muhammad serving as an intercessor leads to a discussion of a third role he plays, as a point of devotion. Using 33:56, in which the Qur'an says believers should send their blessings on Muhammad, we look at the ways in which Muslims do this. 
The most basic form is known as salawat, and we listen to different versions of the salawat from around the world. We then move on to devotional songs, such as qawwali from South Asia, and more contemporary songs, such as American Muslim hip-hop artists, K'naan and Yasiin Bey's (Mos Def) “Prayers Song," and Lupe Fiasco's “Muhammad Walks.” This survey allows students to engage with a living tradition that is manifested through the arts and is present in the United States. The material is less alien to them, and demonstrates how cultural conditions affect the expression of a religion.

\section{Topic 5: Shi'ism}

The earlier discussion on intercession lays the groundwork for the beginning of authority after the death of Muhammad. We ask what roles did Muhammad play, and which, if any, of those roles survive him, and how do they do so. Our first foray into looking at a clearly formed community of interpretation is the Shi'ah Ali, or Partisans of Ali. There is evidence that the theological origins of the community date back to the lifetime of Muhammad (Madelung 1997). Political and legal boundaries of the community developed slightly later, and all predated the formation of what would be called the Sunni community. Therefore, as a matter of historical narrative, it is most accurate to start with the Shi'ah Ali. This unit begins our process of understanding how text is utilized to construct boundaries, and what some of the cultural factors are which are at play in determining those boundaries.

Most of the background reading comes from a textbook on Shi'ism (Haider 2014). The class conversation goes through the various claims to leadership after Muhammad's death. One of the points I highlight is that although we are discussing the Shi'ah Ali (the present-day Shi'ah community), there were other shi'ah (partisans) who supported different figures to succeed Muhammad in different capacities. Therefore, it is inaccurate to speak of a Shi'ah-Sunni divide that goes back to the death of Muhammad. The use of "shi'ah" for different claims to succession makes it easier to highlight that these are conflicts over interpretation, rather than established theological positions and an insurgent theology.

We discuss selections from the Qur'an and hadith related to the role of Muhammad's family. While the preference is for the Shi'ah reading of the texts, we also try to read the texts in a way that is different. Because much of the distinction relies on the way the Arabic is structured, students often have to take my word on what the grammatical issues in the different readings are. However, one verse offers a clear number of readings in translation, and resonates with the discussion in the Qur'an unit on fixing the meaning of text through the act of writing. Echoing the earlier exercise of "woman without her man ...,"I introduce the verse in question (5:55), which states:

Your friend is Allah, and His Messenger, and the believers who observe prayer and pay charity, and worship God alone.

The key clause is "the believers who observe prayer and pay charity." As it is constructed in this translation, the friend of the believer, the one who is connected to God and Muhammad, is the one who prays and offers charity simultaneously. This act is a reference to a story common amongst Shi'ah communities that Ali, the first Imam of the Shi'ah, offered charity whilst in the middle of prayer.

Another way to read the text is to insert an extra comma, so it reads "the believers who observe prayer, and pay charity." This construction has less of a theological impact. God and Muhammad sit apart from other friends of the believer. These friends pray and offer charity as two distinct acts, so a believer should only take a believer as a friend. While not a perfect case study of what the process within Muslim traditions looks like, it is an effective comparison that encourages students to internalize how the process of interpretation functions.

From this early history, I turn to devotional material to emphasize that adherents are participants in the tradition and focus on what it is believers do. The material I use is from around the world, including South Asia and the Levant, as well as devotionals to Ali and Muhammad's family from non-Shi'ah communities in Turkey and India. The point is to destabilize notions of impervious borders between Shi'i and non-Shi'i communities. I end with a lyrical performance of “Love You More" by American performer Amir Sulaiman, to demonstrate the interplay between religion and culture.

152 2021; 2:1 143-158 The Wabash Center Journal on Teaching

This work is licensed under a Creative Commons Attribution-NonCommercial 4.0 International License 


\section{Topic 6: Sufism}

As we turn to Sufism, we are able to build on the work we did on succession to Muhammad, and articulate the different models of authority that emerge in Sufi communities. Many of the arguments that the Shi'ah use to argue for Ali's succession to Muhammad's political, religious, and spiritual authority to be the first Imam are echoed by Sufi communities to argue for Ali as the first Sufi. As a result of this parallel, we are able to do some slightly different work in understanding Sufi communities.

We again read selections of the Qur'an and hadith to understand that an approach of Sufism is the cultivation of an orientation to personal connection to the Divine. We also discuss some of the technical language of the practice of Sufism. However, much of our time is focused on looking at how the same core texts result in a variety of different practices. Many Sufi groups practice a type of devotional known as dhikr, or remembrance. This practice involves the chanting of Divine attributes, selections of the Qur'an, or other devotional material. Some groups do this silently, others do it out loud; some groups do it with still bodies, others do it with bodily movements. Looking and listening to clips of these allows students to witness how a common set of texts can result in distinct practices.

We engage in close reading of poetry, to see how symbols move through time and space and take on new meanings. Since Muslim legal rulings forbid intoxicants, we wrestle with how the symbols of intoxication in Sufi poetry are read within the tradition. We then extend the literary symbols to comparisons of devotional music and dancing as types of intoxicants, to understand the reticence some Muslims have towards engaging in these types of activities.

Perhaps one of the areas where students struggle the most is in understanding that the spiritual quest of Sufis does not mean an absolute withdrawal from the world but often demands a more active engagement with it: an engaged spirituality. While Sufi groups may not be interested in political power, that does not mean that they are apolitical, or have not allied with power. We read Sufism as a critique of power and authoritarianism (Huda 2007b, 695; Huda 2007a, 544; Abbas 2007, 628-632). One of our readings explores the construction of the term "Sufism" in English, and how it is based, in part, on Orientalist understandings of the tradition (Ernst 1997, 1-17). From here we can see how Sufism is constructed as a quietist tradition that represents a "good Islam," but that is not actually how the traditions function or perceive themselves. Through this comparison, we revisit our earlier discussion on how Islam as a whole is studied and presented. As with other units, we look at modern practices of Sufism, including in the United States. We question if those who identify as Sufi, but not Muslim, derive meaning from the sense of a religious community, or if they engage in appropriation. This discussion returns us to questions of power and authority, and the ascriptive ways in which Muslims are defined.

\section{Topic 7: Sunnism and Shari'ah}

By the time the class reaches the unit on Sunni Islam, the basic method of how communities use text to define themselves is fairly well established. In addition, we have discussed the multiple readings of texts. The point of this structure is not to invert the primary focus of study of Islam from Sunnism to Shi'ism, but to utilize an historical, cultural, and discursive approach to understanding the development of the traditions. The premise of the approach is through contestations of authority, with the focus on who gets to lead the community and how that affects expressions of beliefs. The first part of this unit is about understanding the formation of what we now consider the Sunni community in response to the so-called Shi'ah Century, when most of the largest Muslims empires were deeply connected to some sort of Shi'ism (Hodgson 1974b, 36-39). This period in the eleventh century, often misleadingly called the Sunni Revival, is the conglomeration of non-Shi'i groups into a more cohesive identity (Ephrat 2000; Tabbaa 2001).

Since much of the work about defining the community incorporates work from earlier units, we are able to discuss Muslim religious law, shariah, in the second part of the unit. I do not want to tie legal observance only to the Sunni community, so I remind students of the devotional material dedicated to Ali and Muhammad's family that comes out of Sunni communities, and that many Sufis identify as Sunni. I also point out that a Shi'i legal tradition emerges earlier than Sunni traditions. Many Sunni legal scholars studied with Shi'i scholars or Imams (Lalani 2000). This approach allows me to re-emphasize that although there are distinct communities, they are not neatly separated from each other. 
In class, we do a quick exercise on how to interpret texts on intoxication as they apply to coffee and nonalcoholic beer. Using the same sources, we explore how cultural context and knowledge external to religious text influence their interpretations. This connection allows the class to revisit our understanding of religious literacy as being tied to material conditions, broader contexts, and power. I emphasize the question of power in interpretation by looking at several verses in the Qur'an and how they relate to gender. Informed by the work of Amina Wadud (1999), and more recently Ayesha Chaudhry (2013), we look at how text is historically interpreted to center the role of men in society. Returning to the methods we outlined in our first unit, we end the introduction to Islam by reflecting on how our method, informed by questions of religious literacy, challenge a unitary view of what it means to be Muslim.

\section{Considerations}

What I have outlined is a seven-unit introduction to Islam. In most of my contexts, that is seven weeks, one for each unit. However, the methodology is the important part and can be adapted to a variety of circumstances, including less time, limited materials, or not being trained as an Islamicist.

Students are most likely to encounter an introduction to Islam (outside of a dedicated course) in a survey course, like Introduction to World Traditions. In a class that covers a variety of traditions, Islam may only get two weeks. Even in that time, it should be possible to do much of the work of demonstrating how Muslim communities construct their boundaries in relationship with each other. From a content and process perspective, it probably makes the most sense to use the units on the Qur'an (Unit 3) and Prophet Muhammad (Unit 4). It is in these units that one can demonstrate how text functions, how it is interpreted, and how that interpretation connects to succession of Muhammad. By understanding devotion to Muhammad, students should be able to make connections to how different communities of interpretation in that tradition lead to different leadership figures.

Many educators are asked to teach traditions in which we have no specialization, particularly for survey courses. As scholars of religion, we may have taken courses on numerous traditions or taught courses as assistants on traditions outside of our specialization. However, the experience of teaching as the primary instructor for an unfamiliar tradition is qualitatively different. In this instance, I would think of the course as a methods course which the traditions illustrate. Therefore, in content selection and approach, I ask what material allows me to demonstrate the method. Lack of expertise on Islam should not be more of a burden than lack of knowledge of any other religious tradition. I believe the approach that I have outlined in this paper may be portable to teaching diversity in other religious traditions, through a combination of focus on theme and method; in my case, on authority and religious literacy.

\section{Conclusion}

I started by thinking about how to respect the knowledge my students walk into the classroom with. That lead me to better understand the limits of our discipline of religious studies, and the ways those limits affect Islamic studies. In order to teach more effectively, I had to rethink how to approach the Introduction to Islam.

The practice of teaching Islam in the American context has a particular intellectual pedigree. As an educator, I am aware of the critique of the study of religion as emerging out of a normative Christian framework. Edward Said's argument for the ways in which Islam is constructed to meet American political interests, rather than as an engagement with Muslims and their religion, is nearly forty years old.

I want to take the critique of power that scholars of Islam use in our research and think about the ways in which power permeates our discipline. In looking at a more comprehensive representation of Islam, I had to contend with the normalizing work that the discipline does, which is counter to the method I find effective.

While centering nondominant voices is an important start in the process, there is a deeper methodological question at play: Can we talk about a religious tradition without “taking sides?" Each person has their own biases, preferences, and

154 2021; 2:1 143-158 The Wabash Center Journal on Teaching

This work is licensed under a Creative Commons Attribution-NonCommercial 4.0 International License 
research interests. The push is not for an objectivity; such a claim would subvert the very purpose of the paper. Rather, recognizing our own situatedness allows us to push into a more reflective stance on what we are trying to achieve in the field of the study of Islam, located within study of religion.

Looking at how Muslims define their religion through contestation and relation allows students to understand the dynamic nature of the religion. My students may not fully understand the emic notions of religion, even in a fourteenweek introduction to Islam, but they should know that the ascriptive identification given to Muslims is incomplete. We academics can be as complicit in generating that identification as the media or the government. What I outline as an approach gives a greater sense of covering the breadth of material represented by a global religious community with over a millennium of history. Some of my students have gone on to write editorially reviewed op-eds about the diversity of Muslim life, and why it is important for others to know this information (Wiles 2016). These pieces serve as affirmations of my current approach. It is about teaching them about Islam, but also about how to be critical, active, expressive thinkers. While a broader discussion of student learning is beyond the scope of this paper, I am always conscious of trying to understand how students are taking their learning out of the classroom, and how to improve my practice for their learning.

My course structure tries to show the range of Muslims' interactions with their religion, and generates an ongoing tension that prevents either students or myself from making defining, theological claims. This first half of a course establishes space for the second half, where readings are all written by Muslims, to demonstrate the theories we have discussed in practice. It is an attempt to allow the subjects of our study speak for themselves.

\section{B IBLIOGRAPHY}

Abbas, S. B. 2007. "Risky Knowledge in Risky Times: Political Discourses of Qawwālī and Sūfĩana-kalam in PakistanIndian Sufism.” The Muslim World 974: 626-639. https://doi.org/10.1111/i.1478-1913.2007.00204.x.

Ambrose, S. A. 2010. How Learning Works: Seven Research-Based Principles for Smart Teaching. San Francisco, CA: Jossey-Bass.

Asad, T. 1986. The Idea of an Anthropology of Islam. Washington, D.C.: Center for Contemporary Arab Studies, Georgetown University.

Blizek, W. L. 2009. The Continuum Companion to Religion and Film. New York, NY: Continuum.

Bodman, W. 2009. “Reading the Qurān as a Resident Alien.” Muslim World 99 (4): 689-706.

Chan, M. S., Jones, C. R., Jamieson, K. H., and D. Albarracín. 2017. “Debunking: A Meta-Analysis of the Psychological Efficacy of Messages Countering Misinformation.” Psychological Science 28 (11): 1531-1546. https://doi. org/10.1177/0956797617714579.

Chaudhry, A. S. 2013. Domestic Violence and the Islamic Tradition: Ethics, Law, and the Muslim Discourse on Gender. Oxford, UK: Oxford University Press.

Daftary, F. 1996. “Diversity in Islam: Communities of Interpretation.” In The Muslim Almanac: A Reference Work on the History, Faith, Culture, and Peoples of Islam, edited by A. Nanji, 161-173. Detroit, MI: Gale Research.

Daftary, F., and G. Miskinzoda, eds. 2014. The Study of Shi'i Islam: History, Theology and Law. New York, NY: I.B.Tauris in association with the Institute of Ismaili Studies.

During, S. 2005. Cultural Studies: A Critical Introduction. New York, NY: Routledge.

Ecker, U. K. H., Swire, B., and S. Lewandowsky. 2014. "Correcting Misinformation-A Challenge for Education and Cognitive Science." In Processing Inaccurate Information: Theoretical and Applied Perspectives from Cognitive Science and the Educational Sciences, edited by D. Rapp and J. L. G. Braasch, 13-37. Cambridge, MA: MIT Press. 
El-Zein, A. H. 1977. "Beyond Ideology and Theology: The Search for the Anthropology of Islam." Annual Review of Anthropology 6: 227-254. https://doi.org/10.1146/annurev.an.06.100177.001303.

Ephrat, D. 2000. A Learned Society in a Period of Transition: the Sunni "Ulama” of Eleventh Century Baghdad. Albany, NY: State University of New York Press.

Ernst, C. W., and R. C. Martin. 2010. “Introduction: Toward a Post-Orientalist Approach to Islamic Religious Studies.” In Rethinking Islamic Studies: From Orientalism to Cosmopolitanism, edited by C. W. Ernst and R. C. Martin, 1-19. Columbia, S.C.: University of South Carolina Press.

Ernst, C. W. 1997. The Shambhala Guide to Sufism. Boston, MA: Shambhala.

Ernst, C. W. 2003. Following Muhammad: Rethinking Islam in the Contemporary World. Chapel Hill, NC: University of North Carolina Press.

Gaiser, A. 2011. “A Module on Islam.” In Fostering Religious Literacy Across Campus, edited by M. R. Diamond, 28-32. Stillwater, OK: New Forums.

Gaiser, A. 2017. “A Narrative Identity Approach to Islamic Sectarianism.” In Sectarianization: Mapping the New Politics of the Middle East, edited by N. Hashemi and D. Postel, 61-76. Oxford, UK: Oxford University Press.

Gallagher, E. V. 2009. “Teaching for Religious Literacy.” Teaching Theology and Religion 12 (3): 208-221. doi:10.1111/ j.1467-9647.2009.00523.x.

Gallagher, E. V. 2018. "Teaching Religious Studies." In The Oxford Handbook of Religion and American Education, edited by M. Waggoner and N. C. Walker, 425-437. New York, NY: Oxford University Press.

Hahn Tapper, A. J. 2016. Judaisms: A Twenty-First-Century Introduction to Jews and Jewish Identities. Oakland, CA: University of California Press.

Haider, N. I. 2014. Shi'i Islam: An Introduction. Cambridge, UK: Cambridge University Press.

Hashemi, N., and D. Postel. 2017. “Introduction: The Sectarianization Thesis." In Sectarianization: Mapping the New Politics of the Middle East, edited by N. Hashemi and D. Postel, 1-22. Oxford, UK: Oxford University Press.

Hazleton, L. 2010. “On Reading the Koran.” Filmed October 2010 at TEDxRanier. TED video, 9:11. https://www.youtube. com/watch?v=xOnwG GgAqg.

Hodgson, M. G. S. 1974a. The Classical Age of Islam. Chicago, IL: University of Chicago Press.

Hodgson, M. G. S. 1974b. The Expansion of Islam in the Middle Periods. Chicago, IL: University of Chicago Press.

Huda, Q. 2007a. “Introduction.” The Muslim World 97 (4): 543-547. http://dx.doi.org/10.1111/i.14781913.2007.00200.x.

Huda, Q. 2007b. “Memory, Performance, and Poetic Peacemaking in Qawwālī.” The Muslim World 97 (4): 678-700. https://doi.org/10.1111/i.1478-1913.2007.00207.x.

Hussain, A. 2010. "Images of MuDammad in Literature, Art, and Music." In The Cambridge Companion to Muhammad, edited by J. E. Brockopp, 274-292. Cambridge, UK: Cambridge University Press.

Katz, M. H. 2010. “The Prophet MuDammad in Ritual.” In The Cambridge Companion to Muhammad, edited by J. E. Brockopp, 139-157. Cambridge, UK: Cambridge University Press.

156 2021; 2:1 143-158 The Wabash Center Journal on Teaching

This work is licensed under a Creative Commons Attribution-NonCommercial 4.0 International License 
Khoja-Moolji, S. 2014. "Poststructuralist Approaches to Teaching about Gender, Islam, and Muslim Societies.” Feminist Teacher 24 (3): 169. https://doi.org/10.5406/femteacher.24.3.0169.

King, R. 1999. Orientalism and Religion: Post-colonial Theory, India, and the Mystic East. New York, NY: Routledge.

Kurzman, C., and C. W. Ernst. 2012. “Islamic Studies in US Universities.” Review of Middle East Studies 46 (1): $24-46$. https://onlinelibrary.wiley.com/doi/abs/10.1111/i.1467-9647.2009.00523.x.

Lakoff, G. 2014. The All New Don't Think of an Elephant!: Know Your Values and Frame the Debate. White River Junction, VT: Chelsea Green.

Lalani, A. R. 2000. Early Shi'i Thought: The Teachings of Imam Muhammad Al-Baqir. New York, NY: I.B. Tauris in association with the Institute of Ismaili Studies.

Lewinstein, K. 2002. "Recent Critical Scholarship and the Teaching of Islam.” In Teaching Islam, edited by B. M. Wheeler, 46-60. New York, NY: Oxford.

Madelung, W. 1997. The Succession to Muhammad: A Study of the Early Caliphate. New York, NY: Cambridge University Press.

Mamdani, M. 2004. Good Muslim, Bad Muslim: America, the Cold War, and the Roots of Terror. New York, NY: Pantheon Books.

Martin, R. C., and A. Barzegar. 2010. "Formations of Orthodoxy: Authority, Power, and Networks in Muslim Societies." In Rethinking Islamic Studies: From Orientalism to Cosmopolitanism, edited by C. W. Ernst and R. C. Martin, 179202. Columbia, S.C.: University of South Carolina Press.

Masuzawa, T. 2005. The Invention of World Religions: Or, How European Universalism Was Preserved in the Language of Pluralism. Chicago, IL: University of Chicago Press.

Moore, D. L. 2006. “Overcoming Religious Illiteracy: A Cultural Studies Approach.” World History Connected 4 (1). https://rlp.hds.harvard.edu/files/hds-rlp/files/whc.pdf.

Moore, D. L. 2007. Overcoming Religious Illiteracy: A Cultural Studies Approach to the Study of Religion in Secondary Education. New York, NY: Palgrave Macmillan.

Morgenstein Fuerst, I. R. 2014. “Locating Religion in South Asia: Islamicate Definitions and Categories.” Comparative Islamic Studies 10 (2): 217-241. https://doi.org/10.1558/cis.30937.

Nilson, L. B. 2016. Teaching at Its Best: A Research-Based Resource for College Instructors. San Francisco, CA: JosseyBass.

Patton, L. L., Robbins, V. K., and G. D. Newby. 2009. “Comparative Sacred Texts and Interactive Interpretation: Another Alternative to the 'World Religions' Class." Teaching Theology and Religion 12 (1): 37-49. https://doi.org/10.1111/ j.1467-9647.2008.00479.x.

Peter, C., and T. Koch. 2019. “Countering Misinformation: Strategies, Challenges, and Uncertainties.” Studies in Communication and Media 8 (4): 431-445. https://doi.org/10.5771/2192-4007-2019-4-431.

Pew Research Center. 2021. “U.S. Religious Knowledge Quiz.” http://www.pewforum.org/quiz/u-s-religiousknowledge/.

Rashid, H. 2018. “Plural Voices in the Teaching of Islam.” Thresholds in Education 41 (2): 87-100. https:// academyedstudies.files.wordpress.com/2018/06/rashidfinal.pdf. 
Reinhart, A. K. 2002. “On the 'Introduction to Islam.” In Teaching Islam, edited by B. M. Wheeler, 22-45. New York, NY: Oxford.

Said, E. W. 1979. Orientalism. New York, NY: Vintage.

Said, E. W. 1981. Covering Islam: How the Media and the Experts Determine How We See the Rest of the World. New York, NY: Pantheon Books.

Saleh, W. A. 2010. “The Arabian Context of MuDammad's Life.” In The Cambridge Companion to MuDammad, edited by J. E. Brockopp, 21-38. New York, NY: Cambridge University Press.

Salem, H. B. H. 2016. "American Orientalism: How the Media Define What Average Americans Know about Islam and Muslims in the USA." International Journal of Humanities and Cultural Studies 2 (3): 156-172. https://www.ijhcs. com/index.php/ijhcs/article/download/372/374.

Sells, M. A. 1999. Approaching the Qur'an: The Early Revelations. Ashland, OR: White Cloud Press.

Sheikh, Halal. 2012. “Love and Romance in Islam.” YouTube video, 8:05. December 21, 2012. https://www.youtube. com/watch?v=Fx3NRnK $1 \times 9$.

Smith, J. Z. 2014. “Afterword: The Necessary Lie: Duplicity in the Disciplines.” In Studying Religion: An Introduction, edited by R. T. McCutcheon, 74-80. Hoboken, NJ: Taylor and Francis.

Tabbaa, Y. 2001. The Transformation of Islamic Art During the Sunni Revival. Seattle, WA: University of Washington Press.

Wadud, A. 1999. Qur'an and Woman: Rereading the Sacred Text from a Woman's Perspective. New York, NY: Oxford University Press.

Wheeler, B. M. 2002. "What Can't be Left Out: The Essentials of Teaching Islam as a Religion.” In Teaching Islam, edited by B. M. Wheeler, 3-21. New York, NY: Oxford.

Wiles, C. 2016. “What Mark Lowenthal Got Wrong About the 'Islam' in 'Islamic Terror.'” The Paris Globalist, October 12, 2016. http://www.parisglobalist.org/mark-lowenthal-got-wrong-islam-islamic-terror/.

\section{ABOUT THE AUTHOR}

Hussein Rashid is an independent scholar, working at several universities in the New York City area. His research focuses on Muslims and US popular culture, and he is an educator and consultant working on public projects related to religion. 